\title{
Cytokine detection in cerebrospinal fluid in central nervous system diseases in children
}

\section{Stęienie cytokin w płynie mózgowo-rdzeniowym w przebiegu chorób neurologicznych u dzieci}

\author{
Karol Lubarski (D), Anna Mania (D), Katarzyna Mazur-Melewska (iD), Magdalena Figlerowicz (iD) \\ Department of Infectious Diseases and Child Neurology \\ University of Medical Sciences in Poznań, ul. Szpitalna 27/33, 60-572 Poznań \\ DOI:10.20966/chn.2020.59.468
}

\section{ABSTRACT}

Cytokine activation and inflammatory process is a result of complex interaction in the pathogenesis of various central nervous system disorders (CNS). Both proinflammatory and anti-inflammatory cytokines are produced during immune response. Cytokines measurement in the cerebrospinal fluid (CSF) may be used as an additional tool in patients assessment. In the state of CNS infection, IL-1, IL-6, IL-8, IL-10 and TNF- $\alpha$ levels are typically elevated. Cytokine level alterations after antibiotic therapy are not fully elucidated. Some cytokines, like IL-6, are not only an inflammatory parameter, being elevated in patients with subarachnoid haemorrhage. The role of TNF- $\alpha$ is known in neurodegenerative disorders, where levels of proinflammatory factors, including TNF- $\alpha$, IL-1 and IL-6, are increased both in serum and in CSF. Assessment of cytokine levels in CSF may be an additional evaluation tool in the management of CNS disorders in children, especially those of inflammatory background. Therapeutic agents for specific cytokines could be a future tool in the treatment of inflammatory diseases.

Key words: cortisol, autism spectrum disorder, children.

\begin{abstract}
STRESZCZENIE
Aktywacja cytokin i rozwój procesu zapalnego jest wynikiem złożonej interakcji w patogenezie wielu schorzeń ośrodkowego układu nerwowego. Zarówno cytokiny o działaniu prozapalnym, jak i przeciwzapalnym są wytwarzane podczas odpowiedzi immunologicznej. Pomiar cytokin w płynie mózgowo-rdzeniowym może być stosowany jako dodatkowe narzędzie w procesie diagnostycznym pacjentów z chorobami OUN. W zakażeniach OUN o różnej etiologii, stężenia IL-1, IL-6, IL-8, IL-10 i TNF- $\alpha$ są zazwyczaj podwyższone. Zmiany ich poziomu pod wpływem antybiotykoterapii nie są w pełni wyjaśnione. Niektóre cytokiny, jak IL-6 są nie tylko parametrem zapalnym, ulegają również podwyższeniu stanach chorobowych o etiologii niezapalnej, jak np. u pacjentów z krwotokiem podpajęczynówkowym. Rola TNF- $\alpha$ jest znana w zaburzeniach neurodegeneracyjnych, gdzie zarówno w surowicy, jak i w CSF zwiększa się poziom czynników prozapalnych, w tym TNF- $\alpha$, IL-1 i IL-6. Ocena poziomu cytokin w płynie mózgowo-rdzeniowym pacjenta może być dodatkowym narzędziem oceny w leczeniu zaburzeń ośrodkowego układu nerwowego u dzieci, zwłaszcza tych o podłożu zapalnym. Metody leczenia wpływające na stężenia określonych cytokin mogą być przyszłym narzędziem w leczeniu chorób zapalnych OUN.

Słowa kluczowe: cytokiny, płyn mózgowo-rdzeniowy, dzieci, markery.
\end{abstract}

\section{INTRODUCTION}

The cerebrospinal fluid (CSF) surrounds the central nervous system (CNS). Because of mediation between axial nervous system and blood, various constituents' concentration ensures valuable information reflecting general welfare or potentially coexisting illness. Detection of proven markers associated with specific diseases simplifies making a definite diagnosis and encloses researchers to revealing pathogenesis of the disease [1]. Routine biochemical and bacteriological examination of CSF typically includes CSF cell count, levels of protein, glucose and chloride ion and analysis of CSF smear. Additional bacterial culture and polymerase chain reaction PCR offers the detection of the potential causing factor in the cases of CSN infections. In inflammatory and demyelinating disorders, evaluation of CSF proteins and immunoglobulins may be helpful. Available reports admit that routine parameters are not always sensitive enough to detect pathological processes early [2-
5]. More specific diagnostic tools are a reason for searching novel, more reliable and sensitive markers.

Evaluation of CSF cytokine levels may give additional meaningful information in various inflammatory diseases. Complex interactions between cytokine activation and inflammatory process are involved in the pathogenesis of many disorders. Proinflammatory and anti-inflammatory cytokines regulate immune response, both being produced during the infection. IL- $1 \beta$, TNF- $\alpha$, IL- 8 and IL- 6 are proinflammatory cytokines that participate in the induction of acute phase inflammatory reactions. IL-1 receptor antagonist (IL1RA) and IL-10 are anti-inflammatory cytokines. The balance between those two cytokine groups influences the severity of the immune response. The release of proinflammatory cytokines (IL-1, Il-8, TNF- $\alpha$ ) is responsible for developing inflammation in both aseptic and purulent CNS infections that potentially correlate with the disease outcome [6]. In the state of CNS infection, IL-1, IL-6, IL-8, IL-10 and 
TNF- $\alpha$ levels are typically elevated. Cytokine level alterations after antibiotic therapy are not fully elucidated. Some researchers conclude that IL- $1 \beta$ and IL- 8 decreases due to such treatment but others do not confirm that fact [7-8].

\section{IL-1}

IL- 1 is a superfamily consisting of 9 members. IL- $1 \beta$ is the most active, soluble factor, and IL- $1 \alpha$ is a membrane subtype [9]. IL-1 receptor type 1 (IL-1-R1) is the primary receptor responsible for the inflammatory reaction; on the other hand, IL-2 receptor type 2 (IL-1-R2) can decrease IL-1 signal transduction. What is more, IL-1-R2 receptor (IL-1R2) has a higher affinity for IL-1 $\beta$ than IL-1 $\alpha$, which results in the anti-inflammatory effect of IL-1 $[10,11]$. The protein that binds to IL1-R preventing IL1 from sending the signal into the target cell is called IL-1 receptor antagonist (IL-1RA). IL-1RA inhibits the activities of IL-1 and modulates a variety of IL-1 related immune response.

IL-1 $\beta$ is considered to be a major inflammatory cytokine, not only leading to an increase of other cytokine production and BBB permeability [12] but also inducing glial and neuronal degeneration or damage $[13,14]$. IL-1-R2 and IL-1 levels were significantly higher in patients with mumps and enteroviral meningitis than in control [15]. In neuroborreliosis there are suggestions that IL-1Rra are a possibly good indicator of response to antibiotics. In experiments on animals, the administration of IL- $1 \beta$ was responsible for inducing memory deficits with an associated increased level of TNF- $\alpha$ and reduced expression of the glial fibrillary acidic protein (GFAP) [16]. In other research, CSF taken from a patient with multiple sclerosis (MS) in vitro increased postsynaptic excitatory current and provoked neuronal swelling. These results may indicate the possible relation between the inflammatory process and neurodegeneration detectable in the course of the disease. This association has its reflection in clinical findings, which confirms the increase of volume and a number of demyelination lesions in patients with a high concentration of described interleukin. However, there was no detected connection between the number of leukocytes in the CSF and Il-1 $\beta$ level, which excludes its intrathecal production. Furthermore, the lack of IL-1 $\beta$ in neuromyelitis optica (NMO) suggests that cytokine is associated with a chronic process, not the acute phase of the disease $[13,17]$. In other analyses the repeated measurement of IL-1 in the CSF of patients with MS had no significant diagnostic value [18]. In an animal model, IL-1 $\beta$ abnormal concentration (increased or decreased) leads to impairment of hippocampal memory formation, synergic with COX-1 induced prostaglandins during delirium [19]. In this context, it is worth mentioning that chronic IL- $1 \beta$ overproduction by microglial tissue is supposed to be connected with plaque creation preluding neurodegeneration in Alzheimer's disease [19]. The results are coherent with chronic blockage of IL-1R in a mouse model, in which the cognitive impairment was alleviated with coexisting reduction of chosen forms of $A \beta$ and Tau proteins [20]. CSF IL-1 $\beta$ was found significantly higher in children with febrile seizures compared to controls [21].
On the other hand, mice with boosted IL-1RA activity were more likely to develop a lower-volume brain [22]. However, in ischaemia, IL-1 $\beta$ oozing proceeds the IL-1RA synthesis for about 30 minutes. The latter is negatively correlated with GFAP, suggesting its neuroprotective function due to the decreased activation of glial cells [23]. Also in a randomized double-blinded experiment in patients with acute stroke the neuroprotective role of IL-1RA was detected, indicating better prognosis in the cases of cortical infarct [24]. According to assessments on patients with neonatal hypoxic-ischaemic encephalopathy, IL-1 $\beta$ is the best predictive value for neurological sequelae in the age of 6- and 12-months, with the highest ratio between concentration in serum and CSF $[25,26]$. IL-1 $\beta$ is less related to antibiotic treatment than TNF- $\alpha$, making the first a better marker of the marker of the patient's condition at the onset of the disease [27]. In CNS infections an IL-1 $\beta$ measurement is a useful tool in distinguishing two most frequent aetiologies - bacterial and viral. The cytokine has specificity and PPV at $96 \%$ and $95 \%$, with a sensitivity reaching $78 \%$. IL-1 appears to be more elevated in infants with bacterial meningitis, especially in neonates who die of gram-negative infection compared to survivors, being connected with unfavourable prognosis [28]. Furthermore, Low et al. described the correlation between the detection of IL-1 $\beta$ and TNF- $\alpha$ with longer hyperpyrexia, increased muscle tonus, paroxysmal episodes and death rate [29]. Analogous, interleukin- $1 \beta$ is a factor of worse outcome in viral CNS infections. Value of IL-1 $\beta$ :IL-1RA ratio of CSF is significantly associated with low Glasgow Outcome Scale. Moreover, in the same research, IL-1RA serum activity was positively correlated with better treatment results in the general population and lesser temporal lobe swelling in HSV encephalitis patients.

\section{IL-6}

Interleukin- 6 is one of the proinflammatory cytokines secreted by phagocytes, T- and B-lymphocytes and endothelial cells, fibroblasts in response to injury, including infections, trauma and cardiovascular reasons [30,31]. Presented interleukin has many physiological functions, including proliferation, differentiation and apoptosis. It also plays a vital role in nonspecific reaction to infection, which stimulates the production of acute-phase proteins, including fibrinogen and CRP or reflects the BBB function. IL6 level reacts to administered therapy, alternating with the improvement or aggravation of clinical state [32]. Chronic elevation of this cytokine may lead to impairment of the production of several substances and secondary physiology of neurons. Its increase was documented in several disorders with different aetiology, autoimmune and infective ones. Significantly increased mean IL-6 value in patients with bacterial meningitis was described in comparison to the group suffering from aseptic meningitis and the control group with sensitivity and specificity up to $100 \%$ [33,34]. Correlation between IL-6 and CSF leukocyte count and protein level were discovered in both bacterial and viral meningitis. Intriguingly, IL-6 was described as a parameter 
increasing before the first symptoms, when other inflammatory markers were negative, being an early marker of inflammation $[35,36]$. The strong correlation in encephalopathies associated with infectious agents was described, especially in HHV-6, influenza, Japanese encephalitis and tuberculous aetiology. In adults and children with poor prognosis and incomplete recovery concentration of IL-6 was significantly higher than in patients without sequelae $[38,39,40]$. IL-6 is not only described as an inflammatory parameter - available reports link higher values of this cytokine in CSF with subarachnoid haemorrhage and following vascular constriction. Concentration arises in few days after SAH episode and gradually decrease within the next weeks. In ischemic stroke, IL-6 levels are increased in serum and CSF as in SAH, with a predominance of subarachnoid space. There is an association between the clinical state of the patient and IL-6 concentration [30,31]. In the studies concerning acute disseminated encephalomeningitis, IL-6 was suggested as an inflammation mediator of observed disorder - increased concentrations were found in 16 of 18 patients and no one in the control group. Evaluation of psychiatric population revealed a significant positive link between CSF IL-6 level and dysthymia score. The described cytokine's concentration may also be associated with iatrogenic intervention as oncological therapy. It is proven that anthracyclines, cytophosphane or arabinoside derivates may increase interleukins, like IL-6 and TNF- $\alpha$ by induction of subclinical meningoencephalitis [41]. Moreover, a higher level of IL-6 is observed in patients with major depressive disorders [42]. Measurement of CSF IL-6 may help to assess the response to treatment with infliximab in the course of neurosarcoidosis.

\section{IL-8}

IL-8 is a proinflammatory cytokine which is detected in an early period of CNS infection, described aside from IL-1 and IL-6 as one of the essential cytokines responsible for innate immunity. The cytokine promotes interaction between leukocytes and endothelial tissue, responsible for the early phases of inflammatory infiltration or severe ischaemic episode, higher in focal cerebral arteriopathy than in other aetiologies. IL- 8 is described to be an attractant for neutrophils, causing chemotaxis to the inflammation compartment $[35,43]$. Its concentration may be positively associated with significant sequelae of the disease. Moreover, the cytokine was reported to be significantly increased in herpetic, HHV-6, influenza and enteroviral aetiology. The last one may run with increased CSF IL-8, even without pleocytosis. What is more, concentrations are usually higher in bacterial meningitis, giving a chance to distinguish viral and bacterial origin, achieving sensitivity and specificity at the level of $89,5-100 \%$ and $86,7-94 \%$, respectively, depending on the set cutoff level and research $[33,35,43]$. IL-8, the same as TNF- $\alpha$ and IL-6, has similar values in both gram-negative and gram-positive bacteria [44].

\section{IL-10}

IL-10 is an anti-inflammatory cytokine. In patients with acute disseminated encephalomyelitis IL-10 was detected in 13 of 18 patients whereas subjects in the control group had it undetectable. There was no association between IL-10 concentration and CSF protein level or cell count [45]. In bacterial meningitis, the IL-10 level is significantly higher in gram-positive aetiologies than in gram-negative infections. What is more, the cytokine is assessed as one of the main interleukins controlling the containment of proinflammatory factors. Due to the increase of IL-10 the effect of proinflammatory agents is lowered which results in additional neuroprotective role. The concentration of IL-10 is the highest in the recovery phase of both bacterial and viral CNS infections. However, the cytokine is present also in the first period of the disease. A statistically important rise of IL-10 in the later phases of disease was observed in viral infections. In research on animal models the systemic injection of IL-10 resulted in decreased CSF leukocyte count, lowered intracranial pressure and the general suppression of IL-6 effects which confirmed the suppressory character cytokine [46].

\section{TNF- $\alpha$}

TNF- $\alpha$ induces a purposive migration of leukocytes resulting in $\mathrm{BBB}$ disruption, increased permeability, and brain oedema leading to damage to brain tissues, including glial cells and vascular endothelium [46]. Age and sex do not interfere with their level. The first phases of inflammation mediated by TNF- $\alpha$ are associated with induction of IL-1 $\beta$ production, making those two cytokines responsible for early initiation of generalized reaction [41]. TNF- $\alpha$ concentration in serum may help to determine the aetiological factor of CNS infection. Few studies noticed that TNF- $\alpha$ was increased in most bacterial meningitis patients, whereas none of the viral cases was associated with such laboratory finding $[33,34,47,48]$. On the other hand, some authors describe the elevation of TNF- $\alpha$ in certain CNS infections, including caused by HSV-1, HHV-6, enterovirus, mumps, influenza or Japanese encephalitis virus. The parameter is linked to the observed outcome and the possibility of complications [40-47]. TNF- $\alpha$ intermediates an inflammatory process in non-infectious disorders. Tumour necrosis factor receptor 1 (sTNFR1) was found in increased concentration in 11 out of 18 patients with acute disseminated encephalomyelitis. What is more, sTNFR-1 and IL-10 correlated with each other. As TNF- $\alpha$ is assumed as one of the primary mediators in inflammatory processes, the balance with anti-inflammatory cytokines is vital to prevent the injury of glial cells and demyelination in the acute phase of the disease [46]. The same pathophysiology is probably responsible for systemic vasculitis resulting in Kawasaki disease (KD) in which high concentrations of sTNFR1and IL-6 are described. The role of TNF- $\alpha$ is known in neurodegenerative disorders, where both in serum and in CSF levels of proinflammatory factors including TNF- $\alpha$, IL1 and IL-6, are increased. In multiple sclerosis patients described factor is a rare nonspecific finding [49]. TNF- $\alpha$, as it was mentioned before, induces apoptotic processes; this relation is observable also in ischemic events where the intensive release of such cytokine takes place within a first day-first week after hypoxic-ischemic injury [50]. 


\section{CONCLUSION}

IL-1 belongs to the group of early markers of disease appearing during the first hours after onset. As a sensitive marker may reflect the actual disease activity the efficiency of antibiotic therapy of neuroinfections, including neuroborreliosis [28]. IL-6 is described as an early inflammatory indicator in neuroinfections [35], in both ischemic and haemorrhagic disorders including strokes [30,31], as well as reaction to administered therapy [41] or mechanical damage [51]. Its concentration remains elevated according to the disease activity [31-32]. In SAH IL-6 reaches the highest value within few first days, then gradually decreases through next weeks. IL-8 appears in the first phases of disorders, early period of ischaemic episodes, infectious and non-infectious CNS disorders [43]. TNF- $\alpha$ is a non-specific CNS injury most often found in the first phases of generalized reaction [42]. Often described as the first circulating and activating other cytokines pathways. The significant concentration elevation appears in neuroinflammatory diseases as encephalitis, meningitis or CNS trauma [51], in ADEM we observe a decrease in CSF level [45]. IL-10 is a cytokine of the convalescent, late phase of disease. As an anti-inflammatory agent dampens the proinflammatory interleukins mentioned above, leading to their decrease in CSF after neuroinfection [45], autoimmune disorders, other CNS damage or chemical irritation [41]. Assessment of cytokine levels in a CSF patient may be additional evaluation additional evaluation tool in the management of CNS disorders in children, especially those of inflammatory background. The summary of cytokine patterns observed in various disorders with described cytokine dynamics in selected clinical cases was presented in Table 1.

Tab. I Therapeutic agents for specific cytokines could be a future tool in the treatment of inflammatory diseases.

\begin{tabular}{|c|c|c|}
\hline Disorder & cytokine pattern & cytokine dynamics \\
\hline $\begin{array}{l}\text { Nonspecific CNS } \\
\text { injury (infections, } \\
\text { trauma, } \\
\text { cardiovascular) }\end{array}$ & $\begin{array}{l}\text { - generalised IL-6 increase [30,31], - TNF- } \alpha \text { - early phases of } \\
\text { generalised reaction [41] - TNF- } \alpha \text { mediated IL-1 } \alpha \text { production [41] }\end{array}$ & $\begin{array}{l}\text { In Traumatic Brain Injury the parameters were } \\
\text { controlled every } 12 \mathrm{~h} \text {. IL-1 } \alpha \text {, IL- } 1 \alpha \text {, and IL- } 6 \text { were } \\
\text { increased - their dynamic was not steady. IL- } 10 \text { had } \\
\text { the highest level around } 24 \mathrm{~h} \text { after the injury. The } \\
\text { TNF- } \alpha \text { had two peaks - first higher after } 36 \mathrm{~h} \text { and the } \\
\text { later } 84 \mathrm{~h} \text {. [51] }\end{array}$ \\
\hline $\begin{array}{l}\text { both bacterial } \\
\text { and viral } \\
\text { neuroinfection }\end{array}$ & $\begin{array}{l}\text { - IL-6 early inflammatory factor [35] reflects the therapy efficiency } \\
\text { and clinical state in neuroinfection [32] - IL-6 correlates with CSF } \\
\text { cytosis and protein concentration [36] - IL-10 - the highest in the } \\
\text { recovery phase of both bacterial and viral CNS infections, also } \\
\text { present in the first period of the disease [46] - IL-10 statistically } \\
\text { rises higher in later phases of viral infection [46] }\end{array}$ & $\begin{array}{l}\text { In aseptic meningitis, all patients with moderately } \\
\text { increased IL-6 in the early phase after } 8 \text { days of } \\
\text { hospitalization had the cytokine near the normal } \\
\text { level. [52] In bacterial meningitis, all patients had } \\
\text { highly increased IL-6, after } 14 \text { days } 3 / 9 \text { emained the } \\
\text { cytokine excessing the normal value. [52] }\end{array}$ \\
\hline $\begin{array}{c}\text { bacterial } \\
\text { neuroinfection }\end{array}$ & $\begin{array}{l}\text { - elevated IL-1 connects with unfavourable prognosis [27]; IL-1 } \alpha \text { is } \\
\text { better patient condition marker at the onset of the disease [28] - IL- } \\
\text { 1Ra is a good indicator of response to antibiotics in neuroborreliosis } \\
\text { - mean IL-6 value statistically higher than in viral [33] } \\
\text { - IL-8 concentration higher than in viral [33,35] } \\
\text { - TNF- } \alpha \text { is increased in most bacterial meningitis, no association in } \\
\text { viral cases }[33,34,47,48]\end{array}$ & \\
\hline $\begin{array}{c}\text { viral } \\
\text { neuroinfection } \\
\text { and aseptic CNS } \\
\text { inflammation) }\end{array}$ & $\begin{array}{l}\text { - IL-1 } \beta \text { is a factor of worse outcome [29] } \\
\text { - IL-1 } \beta \text { :IL-1RA ratio of CSF is significantly associated with low } \\
\text { Glasgow Outcome Scale [29] } \\
\text { - mean IL-6 value statistically lower than in bacterial [33] - } \\
\text { IL-6 concentration is higher (in HHV-6, influenza, Japanese } \\
\text { encephalitis) in patients with complications, incomplete recovery } \\
\text { and poor prognosis [38,39] } \\
\text { - IL-8 (in herpetic, HHV-6, influenza and enteroviral) is positively } \\
\text { associated with significant sequelae [35] } \\
\text { - Patients with HSV encephalitis with normal GCS have increased } \\
\text { IL-10 [29] - In recovery phase IL-10 is significantly higher than in } \\
\text { acute phase [53] - TSF- } \alpha \text { (in HSV-1, HHV-6, enterovirus, mumps, } \\
\text { influenza or Japanese encephalitis virus) is linked to the outcome } \\
\text { and the possibility of complications [40-47] }\end{array}$ & $\begin{array}{l}\text { Enteroviral neuroinfection. } 1) \text { The IL-6, IL-8 and IL-10 } \\
\text { concentrations were tested in the acute phase } \\
(2.4 \pm 1.6 \text { days after onset) and in the recovery } \\
\text { phase (11.4 } \pm 3.9 \text { days after onset). IL-10 increased } \\
\text { significantly and was higher in the late period, } \\
\text { whereas IL-6 and IL-8 were higher at first and } \\
\text { decreased during control [53]. } \\
\text { 2) The CSF IL-1 } \beta \text {, IL-6 and IL-8 levels in critically and } \\
\text { severely ill patients were significantly higher in the } \\
\text { acute phase (within } 6 \mathrm{~h} \text { of admission) and decreased } \\
\text { in recovery phase (after 7-14 days of treatment) [54] }\end{array}$ \\
\hline $\begin{array}{l}\text { neurodegenerative } \\
\text { disorders }\end{array}$ & $\begin{array}{l}\text { - in MS proinflammatory factors are increased in active phase } \\
\text { - TNF- } \alpha \text {, IL-1 and IL-6 are increased; IL-10 increased during } \\
\text { remission [55] } \\
\text { - in MS, repeated measurement of IL-1 has no significant } \\
\text { diagnostic value [18] } \\
\text { - in AD, IL-1 } \beta \text { microglial tissue overproduction links with plaque } \\
\text { creation [19] }\end{array}$ & $\begin{array}{c}\text { The patients with MS in remission or stable } \\
\text { phase lasting at least } 3 \text { months have higher IL-10 } \\
\text { concentration than patients in MS active phase of } \\
\text { disease (new symptoms and signs or worsening of } \\
\text { an old for at least } 24 \text { hours within } 2 \text { weeks before } \\
\text { sampling). In the latter group TNF- } \alpha \text { was increased. } \\
\text { [55] }\end{array}$ \\
\hline
\end{tabular}




\begin{tabular}{|c|c|c|}
\hline Disorder & cytokine pattern & cytokine dynamics \\
\hline $\begin{array}{c}\text { stroke and } \\
\text { ischaemic disorders }\end{array}$ & $\begin{array}{l}\text {-in ischaemia and vessel constriction IL-1 } \beta \text { oozing } \\
\text { proceeds the IL-1Ra synthesis for about } 30 \text { minutes [23] } \\
\text { - in stroke, the neuroprotective role of IL-1Ra links with } \\
\text { better prognosis in the cortical infarct [24] } \\
\text { - IL-6 concentration connects with a disease severity [31] } \\
\text { - IL-8 - early period severe ischaemic episode [43] }\end{array}$ & \\
\hline $\begin{array}{l}\text { subarachnoid } \\
\text { haemorrhage }\end{array}$ & $\begin{array}{l}\text { - in SAH, IL-6 in CSF reaches higher values; concentration } \\
\text { arises in few days after episode and gradually decreases } \\
\text { within the next weeks [30] } \\
\text { - IL-6 associates with the clinical state of the patient [30] }\end{array}$ & $\begin{array}{l}\text { After the subarachnoid haemorrhage the IL- } 6 \text { increased. The } \\
\text { highest values were observed within } 24 \mathrm{~h} \text {. Next assessments } \\
\text { in } 1 \text { and } 5 \text { day showed a decrease, but the concentration } \\
\text { remained elevated [56] }\end{array}$ \\
\hline ADEM & $\begin{array}{l}\text { - IL-6 is an inflammatory mediator, increased } \\
\text { concentration appears in excessive majority of patients } \\
\text { [45] - increased IL-10 is detected in the majority of } \\
\text { patients, - TNF- } \alpha \text { activity - one of the primary mediators } \\
\text { in inflammatory processes is elevated in majority of } \\
\text { cases; correlates with IL-10 concentration [45] } \\
\text { - No correlation between the IL-6, IL-10, or sTNFR1 } \\
\text { level and the CSF protein concentration or CSF } \\
\text { cell count [45], in induced inflammation IL-10 was } \\
\text { associated with CSF protein level [46] }\end{array}$ & $\begin{array}{l}\text { In ADEM both IL- } 6 \text { and IL-10 decreased in repeated CSF } \\
\text { analyse, but only in selected cases below the upper normal } \\
\text { limit. The median interval between CSF examination lasted } \\
\qquad 13,5 \text { days }[45]\end{array}$ \\
\hline depressive disorders & $\begin{array}{l}\text { - CSF IL-6 level links with dysthymia score [41], - the } \\
\text { higher level of IL-6 is observed in patients with major } \\
\text { depressive disorders [42] - TNF- } \alpha \text {, IL-1ß and IL-10 } \\
\text { remained unaffected [42] }\end{array}$ & $\begin{array}{l}\text { In experimental model E. coli endotoxin was injected and } \\
\text { patient observed for } 24 \mathrm{~h} \text {. CSF IL-6 significantly raised in } \\
\text { comparison to placebo group. The IL-6 peak appeared } 6 \mathrm{~h} \\
\text { after injection, TNF-(a) and IL-10 concentration in CSF } \\
\text { did not elevated. CSF IL-6 raised slower than in serum, in } \\
\text { the latter the maximum values were observed in } 2 \mathrm{~h} \text { after } \\
\text { injection. Patients with induced inflammation experienced } \\
\text { dysthymia [42]. }\end{array}$ \\
\hline $\begin{array}{c}\text { Response to } \\
\text { therapy }\end{array}$ & $\begin{array}{l}\text { - IL-6 eases an assessment of the response to infliximab } \\
\text { treatment } \\
\text { - During the oncological therapy with anthracyclines, } \\
\text { cytophosphane or arabinoside increased IL-6 and TNF- } \alpha \\
\text { are observed [41] }\end{array}$ & \\
\hline \multicolumn{3}{|c|}{$\begin{array}{l}\text { Table } 1 \text { The summary of cytokine patterns observed in various disorders with described cytokine dynamics in selected clinical cases. } \\
\text { ADEM - Acute Disseminated Encephalomyelitis; CNS - Central Nervous System; CSF - cerebrospinal fluid; IL - interleukin; MS - Multiple } \\
\text { Sclerosis; TNF- } \alpha \text { - Tumor Necrosis Factor- } \alpha \text {; SAH - Subarachnoid Haemorrhage; sTNFR1 - soluble TNF receptor } 1\end{array}$} \\
\hline
\end{tabular}

\section{BIBLIOGRAPHY}

[1] Hühmer A.F., Biringer R.G., Amato H., et al.: Protein Analysis in Human Cerebrospinal Fluid: Physiological Aspects, Current Progress and Future Challenges. Dis Markers 2006; 22: 3-26.

[2] Petry F., Torzewski M., Bohl J., et al.: Early Diagnosis of Acanthamoeba Infection during Routine Cytological Examination of Cerebrospinal Fluid. J Clin Microbiol 2006; 44: 1903-1904.

[3] Pfisterer W.: Early diagnosis of external ventricular drainage infection: results of a prospective study. J Neurol Neurosurg Psychiatry 2003; 74: 929-932.

[4] Dougherty J.M., Jones J.: Cerebrospinal fluid cultures and analysis. Ann Emerg Med 1986; 15: 317-323.

[5] van de Beek D., de Gans J., Spanjaard L., et al.: Clinical Features and Prognostic Factors in Adults with Bacterial Meningitis. N Engl J Med 2004; 351: 1849-1859.

[6] Dalal I., Tzhori S., Somekh E., et al.: Cytokine profile in cerebrospinal fluid of children with echovirus type 4 meningitis. Pediatr Neurol 2003; 29: 312-316.

[7] Cepok S., Zhou D., Vogel F., et al.: The immune response at onset and during recovery from Borrelia burgdorferi meningoradiculitis. Arch Neurol 2003; 60: 849-855.

[8] Cerar T., Ogrinc K., Lotrič-Furlan S., et al.: Diagnostic Value of Cytokines and Chemokines in Lyme Neuroborreliosis. Clin Vaccine Immunol 2013; 20: 1578-8154.
[9] Zheng Y., Humphry M., Maguire J.J., et al.: Intracellular interleukin-1 receptor 2 binding prevents cleavage and activity of interleukin-1 $\alpha$, controlling necrosis-induced sterile inflammation. Immunity 2013; 38: 285-925.

[10] Peters V.A., Joesting J.J., Freund G.G.: IL-1 receptor 2 (IL-1R2) and its role in immune regulation. Brain Behav Immun 2013; 32: 1-8.

[11] Goshen I., Yirmiya R.: Interleukin-1 (IL-1): a central regulator of stress responses. Front Neuroendocrinol 2009; 30: 30-45.

[12] Seppi D., Puthenparampil M., Federle L., et al.: Cerebrospinal fluid IL$1 \beta$ correlates with cortical pathology load in multiple sclerosis at clinical onset. J Neuroimmunol 2014; 270: 56-60.

[13] Ye L., Huang Y., Zhao L., et al.: IL-1 $\beta$ and TNF- $\alpha$ induce neurotoxicity through glutamate production: a potential role for neuronal glutaminase. J Neurochem 2013; 125: 897-908.

[14] Song C., Zhang Y., Dong Y.: Acute and subacute IL-1 $\beta$ administrations differentially modulate neuroimmune and neurotrophic systems: possible implications for neuroprotection and neurodegeneration. J Neuroinflammation 2013; 10: 826 [14 screen pages] Address:[15 screen pages] Address: https://jneuroinflammation.biomedcentral.com/ articles/10.1186/1742-2094-10-59\# citeas.

[15] Sulik A., Kroten A., Wojtkowska M., et al.: Increased Levels of Cytokines in Cerebrospinal Fluid of Children with Aseptic Meningitis Caused by Mumps Virus and Echovirus 30. Scand J Immunol 2014; 79: 68-72. 
[16] Rossi S., Furlan R., De Chiara V., et al.: Interleukin-1 $\beta$ causes synaptic hyperexcitability in multiple sclerosis. Ann Neurol 2012; 71: 76-83.

[17] Popescu B.F.G., Bunyan RF, Parisi JE, et al.: A case of multiple sclerosis presenting with inflammatory cortical demyelination. Neurology 2011; 76: 1705-1710.

[18] Maimone D., Gregory S., Arnason B.G., et al.: Cytokine levels in the cerebrospinal fluid and serum of patients with multiple sclerosis. $J$ Neuroimmunol 1991; 32: 67-74.

[19] Spulber S., Bartfai T., Schultzberg M.: IL-1/IL-1RA balance in the brain revisited - evidence from transgenic mouse models. Brain Behav Immun 2009; 23: 573-579

[20] Griffin É.W., Skelly D.T., Murray C.L., et al.: Cyclooxygenase-1-dependent prostaglandins mediate susceptibility to systemic inflammation-induced acute cognitive dysfunction. J Neurosci Off J Soc Neurosci 2013; 33: 15248-15258.

[21] Kwon A., Kwak B.0., Kim K., et al.: Cytokine levels in febrile seizure patients: A systematic review and meta-analysis. Seizure 2018; 59: 5-10.

[22] Kitazawa M., Cheng D., Tsukamoto M., et al.: Blocking Interleukin-1 Signaling Rescues Cognition, Attenuates Tau Pathology, and Restores Neuronal $\beta$-Catenin Pathway Function in an Alzheimer's Disease Model. J Immunol Baltim Md 2011; 187: 6539-6549.

[23] Oprica M., Hjorth E., Spulber S., et al.: Studies on brain volume, Alzheimerrelated proteins and cytokines in mice with chronic overexpression of IL-1 receptor antagonist. J Cell Mol Med 2007; 11: 810-825.

[24] Emsley H.C.A., Smith C.J., Georgiou R.F., et al.: A randomised phase II study of interleukin-1 receptor antagonist in acute stroke patients. $J$ Neurol Neurosurg Psychiatry 2005; 76: 1366-1372.

[25] Oygur N., Sonmez 0., Saka 0., et al.: Predictive value of plasma and cerebrospinal fluid tumour necrosis factor- $\alpha$ and interleukin$1 \beta$ concentrations on outcome of full term infants with hypoxic-ischaemic encephalopathy. Arch Dis Child Fetal Neonatal Ed 1998; 79: F190-3.

[26] Aly H., Khashaba M.T., El-Ayouty M., et al.: IL-1 $\beta$, IL-6 and TNF- $\alpha$ and outcomes of neonatal hypoxic ischemic encephalopathy. Brain Dev 2006; 28: 178-182

[27]. Boeer K., Vogelsang $H_{.}$, Deufel T., et al.: Immediate diagnosis of ventriculits: evaluation of parameters independent of microbiological culture. Acta Neurochir 2011; 153: 1797-1805.

[28] McCracken G.H., Mustafa M.M., Ramilo 0., et al.: Cerebrospinal fluid interleukin 1-beta and tumor necrosis factor concentrations and outcome from neonatal gram-negative enteric bacillary meningitis. Pediatr Infect Dis J 1989; 8: 155-159.

[29] Low P.S., Lee B.W., Yap H.K., et al.: Inflammatory response in bacterial meningitis: cytokine levels in the cerebrospinal fluid. Ann Trop Paediatr 1995; 15: 55-59.

[30] Vlachogiannis P., Hillered L., Khalil F., et al.: Interleukin-6 Levels in Cerebrospinal Fluid and Plasma in Patients with Severe Spontaneous Subarachnoid Hemorrhage. World Neurosurg 2019; 122: e612-8.

[31] Moreno V.P., Subirá D., Meseguer E., et al.: IL-6 as a biomarker of ischemic cerebrovascular disease. Biomark Med 2008;2:125-136.

[32] Heinrich P.C., Castell J.V., Andus T.: Interleukin-6 and the acute phase response. Biochem J 1990; 265: 621-636.

[33] Prasad R., Kapoor R., Srivastava R., et al.: Cerebrospinal Fluid TNF- $\alpha$, IL-6, and IL-8 in Children With Bacterial Meningitis. Pediatr Neurol 2014; 50: 60-65.

[34] Matsuzono Y., Narita M., Akutsu Y., et al.: Interleukin-6 in cerebrospinal fluid of patients with central nervous system infections. Acta Paediatr 1995; 84: 879-883.

[35] Pinto Junior V.L.L., Rebelo M.C., Gomes R.N., et al.: IL-6 and IL-8 in cerebrospinal fluid from patients with aseptic meningitis and bacterial meningitis: their potential role as a marker for differential diagnosis. Braz $\mathrm{J}$ Infect Dis 2011; 15: 156-158.

[36] Azuma H., Tsuda N., Sasaki K., et al.: Clinical significance of cytokine measurement for detection of meningitis. J Pediatr 1997; 131: 463-465.
[37] Buck C., Bundschu J., Gallati H., et al.: Interleukin-6: a sensitive parameter for the early diagnosis of neonatal bacterial infection. Pediatrics 1994; 93: $54-58$.

[38] Hasegawa S., Matsushige T., Inoue H., et al.: Serum and cerebrospina fluid cytokine profile of patients with 2009 pandemic H1N1 influenza virus-associated encephalopathy. Cytokine 2011; 54: 167-172.

[39] Ichiyama T., Ito Y., Kubota M., et al.: Serum and cerebrospinal fluid levels of cytokines in acute encephalopathy associated with human herpesvirus-6 infection. Brain Dev 2009; 31: 731-738.

[40] Winter P.M., Dung N.M., Loan H.T., et al.: Proinflammatory cytokines and chemokines in humans with Japanese encephalitis. J Infect Dis. 1 listopad 2004; 190: 1618-1626.

[41] Protas P., Holownia A., Muszynska-Roslan K., et al.: Cerebrospinal Fluid IL-6, TNF- $\alpha$ and MCP-1 in children with acute lymphoblastic leukaemia during chemotherapy. Neuropediatrics 2011; 42: 254-256.

[42] Engler H., Brendt P., Wischermann J., et al:: Selective increase of cerebrospinal fluid IL-6 during experimental systemic inflammation in humans: association with depressive symptoms. Mol Psychiatry 2017; 22: $1448-5144$.

[43]. Kothur K., Troedson C., Webster R., et al.: Elevation of cerebrospinal fluid cytokine/chemokines involved in innate, T cell, and granulocyte inflammation in pediatric focal cerebral arteriopathy. Int J Stroke 2019; 14: $154-158$.

[44] Srinivasan L., Kilpatrick L., Shah S.S., et al.: Cerebrospinal fluid cytokines in the diagnosis of bacterial meningitis in infants. Pediatr Res 2016; 80: $566-572$.

[45] Ichiyama T., Shoji H., Kato M., et al.: Cerebrospinal fluid levels of cytokines and soluble tumour necrosis factor receptor in acute disseminated encephalomyelitis. Eur J Pediatr 2002; 161: 133-137.

[46] Koedel U., Bernatowicz A., Frei K., et al.: Systemically (but not intrathecally) administered IL-10 attenuates pathophysiologic alterations in experimental pneumococcal meningitis. J Immunol 1996; 157: 185191.

[47]. Glimaker M., Kragsbjerg P., Forsgren M., et al.: Tumor Necrosis Factor(TNF ) in Cerebrospinal Fluid from Patients with Meningitis of Different Etiologies: High Levels of TNF Indicate Bacterial Meningitis. J Infect Dis 1993; 167: 882-889.

[48] Lopez-Cortes L.F., Cruz-Ruiz M., Gomez-Mateos J., et al.: Measurement of Levels of Tumor Necrosis Factor- and Interleukin-1 in the CSF of Patients with Meningitis of Different Etiologies: Utility in the Differential Diagnosis. Clin Infect Dis 1993; 16: 534-539.

[49] Taira N., Kamei S., Morita A., et al.: Predictors of a prolonged clinical course in adult patients with herpes simplex virus encephalitis. Intern Med Tokyo Jpn 2009; 48: 89-94.

[50] Nakajima W., Ishida A., Lange M.S., et al.: Apoptosis Has a Prolonged Role in the Neurodegeneration after Hypoxic Ischemia in the Newborn Rat. J Neurosci 2000; 20: 7994-8004.

[51] Abboud A., Mi Q., Puccio A., et al.: Inflammation Following Traumatic Brain Injury in Humans: Insights from Data-Driven and Mechanistic Models into Survival and Death. Front Pharmacol 2016 27: 7: 342.

[52]. Matsuzono Y., Narita M., Akutsu Y., et. al.: Interleukin-6 in cerebrospinal fluid of patients with central nervous system infections. Acta Paediatrica 1995; 84: 879-883

[53] Sato M., Hosoya M., Honzumi K., et al.: Cytokine and Cellular Inflammatory Sequence in Enteroviral Meningitis. Pediatrics 2003; 112: 1103-1107.

[54] Ye N., Gong X, Pang L, et al: Cytokine responses and correlations thereof with clinical profiles in children with enterovirus 71 infections. BMC Infect Dis 2015: 225.

[55] Perrella 0., Sbreglia C., Perrella M., et al.: Interleukin-10 and tumor necrosis factor-alpha: model of immunomodulation in multiple sclerosis. Neurological Research 2006; 28: 193-195.

[56] Niwa A., Osuka K., Nakura T., et al.: Interleukin-6, MCP-1, IP-10, and MIG are sequentially expressed in cerebrospinal fluid after subarachnoid hemorrhage. J Neuroinflammation 2016; 13: 217. 